\title{
Social justice as a foundation for democracy and health
}

\author{
Jennifer Prah Ruger uses the covid-19 pandemic to show the importance of countries \\ implementing a justice framework for health and equality
}

T he connection between democracy and health runs deep, and it is tempting to tie a country's political institutions directly to its overall health. A country's political structure, however, influences essentially every facet of society, including health, and thus interactive and interdependent effects work in multiple directions. Democracy is but one determinant of health. And even democratic societies produce different levels and distributions of health and access to healthcare.

The type of political system-democratic or authoritarian, proportional or majoritarian, multiparty or single party, centralised or fragmented, presidential or parliamentary-affects whether government is working by and for the people. But other elements, including political values and public opinion; political leadership; political organisation, strategy, and tactics; corruption levels; financial influence; and interest group representation, are important too. Whether power is separated in a democracy and by how much affects the workings of executive, legislative, and judicial branches.

Democratic principles, such as civil and political liberties, representation, universal suffrage, and free, regular, and fair elections produce competition

\section{KEY MESSAGES}

- The connection between democracy and health is multidirectional and based on social justice

- A fundamental determinant of an effective covid-19 response is justice in societal and individual capabilities

- Both governments and citizens in successful countries recognised their moral obligation to protect themselves and others, especially vulnerable groups

- Without ethical standards, neither democratic nor authoritarian political systems can respond effectively to a pandemic for popular support among politicians ambitious to retain or win elected office. As such, democracy in theory supports health by focusing attention on social, economic, and healthcare inequalities. ${ }^{1}$

By contrast, unrepresentative government and suppressed public debate in theory produce lower political responsiveness and diminish incentives to allocate benefits to certain groups, such as vulnerable people, or universally. A lack of democratic institutions, particularly multiparty elections and a free press, arguably has negative health effects. ${ }^{1}$ Authoritarianism's suppression of political competition and civil liberties can shut down mobilisation of citizens for more resources and for health, social, and economic security.

Quantitative comparisons of authoritarian and democratic regimes in different countries are difficult to make. The covid19 pandemic, however, is a natural experiment revealing the inner workings of the management of public health threats and offering insights about how nations' political systems affect health.

From a justice view grounded in freedoms and capabilities, ${ }^{2}$ the degree to which national actions (or inaction) affect health for all is the measure of their success or failure. Assessing countries' covid-19 responses by justice standards helps reveal the relation between health and political institutions.

\section{Justice in the covid-19 pandemic}

The covid-19 pandemic demonstrates that the fundamental determinant of an effective national response is whether a country operates a justice framework. This is because protecting and promoting the central health capabilities-preventing premature mortality and avoidable morbidityfor all is a problem of justice not politics. Justice, not politics, forms the foundation of what citizens owe each other and what leaders owe citizens.

Effective pandemic preparedness, the ability to anticipate, detect, and coordinate response and recovery, ${ }^{3}$ is a collective capability. Pandemic risk reduction is a global common good that benefits all nations and individuals; it is a duty. ${ }^{4}$ The moral obligation for reducing pandemic risk lies with national governments, which are best positioned to coordinate across levels and sectors of governance. National governments fulfil this obligation through humane, effective, and efficient action. An effective pandemic response also requires individual capabilities-citizens doing their part to reduce contagion.

Fulfilling this moral obligation requires ethical leadership. Ethical leadership, in both leaders and citizens, is necessary for a just society and for effective political institutions because people's and systems' capabilities are what determine whether public health policy succeeds or fails. Ethical leadership's hallmarks are honesty, transparency, impartiality, and integrity. Ethical leaders promote ethical beliefs and values and show regard for all people. They are committed to the common good.

From a justice viewpoint, national governments that sought to fulfil their moral obligation to act according to the current state of knowledge in pandemic preparedness were more successful in dealing with covid-19 than those who failed to do so. This is because countries that internalised the positive duty to develop and implement systems to reduce threats to and safeguard individuals' and communities' ability to flourish ${ }^{4}$ were more successful in preparing for, preventing, and controlling covid-19. Successful nations set ethical standards for building and operating robust public health systems for resilient individuals and communities. Without ethical standards, neither democratic nor authoritarian political systems can be effective in a pandemic response.

\section{Justice at work in democratic nations}

Some of the most successful covid-19 responses worldwide have occurred in Taiwan, South Korea, Japan, New Zealand, Germany, Austria, Finland, Denmark, Iceland, and Norway. ${ }^{5-7}$ The governments 
of these countries were able to respond quickly and effectively because they steep their responses in justice, recognising mutual interdependencies and shared vulnerabilities. Underlying their covid-19 responses are shared values and shared responsibility and a goal of securing capabilities for all.

All of these countries have robust public health systems supporting resilient communities and individuals; they fulfil these moral obligations to safeguard human flourishing and reduce threats to it. In particular, they exhibit four characteristics of a justice framework for a resilient covid-19 response: governing for the common good; shared responsibility for scientifically grounded systems; rational, compassionate, and transparent communication; and ethical leadership and trust.

\section{Governing for the common good}

These successful countries use shared health governance to help prevent premature mortality and avoidable morbidity. ${ }^{8}$ Efficient healthcare and public health systems require shared responsibility, shared resources, and shared sovereignty. Private actors and public institutions engage collectively to ensure the health and flourishing of all. In shared health governance, genuine collective action brings about justice.

Narrow self-interest does not foster capabilities. The United States, United Kingdom, Brazil, and Russia, all democracies, have shown the failure of leaders who seek to deflect criticism or protect their personal and political interests. By contrast, the shared health governance approach in successful countries, rising above self-interest and focusing on the common good, has enlisted institutions and practices to ensure effective responses to covid-19.

\section{Shared responsibility for scientifically grounded systems}

Shared responsibility for scientifically grounded systems meets the moral obligation to act according to the current state of knowledge in pandemic preparedness. As the pandemic began, successful countries implemented rigorous systems of detection, contact tracing, isolation, quarantine, and social distancing. Taiwan, Japan, South Korea, New Zealand, Germany, and Austria all imposed a quarantine on people arriving from abroad. ${ }^{9-11}$ Taiwan's authorities arranged for special transport to take anyone arriving with a fever to healthcare facilities, which are accessible to all through Taiwan's national health insurance. ${ }^{12}$ Healthcare is also universal, accessible to everyone, in New Zealand, South Korea, Japan, Germany, Austria, Denmark, Iceland, and Finland. While inequity in health is morally unacceptable, so far inequalities in infection and death rates as well as inequality overall seem to be lower in these countries than in unsuccessful countries. Successful countries developed and operationalised health and social systems necessary to prevent, reduce, and mitigate the collective risks emerging if marginalised, vulnerable groups lack social and health protections. The opposite occurred in countries such as the US that lack such systems.

Successful countries rapidly rolled out medically necessary equipment and supplies, tapped surge manufacturing capabilities, and targeted diagnostics and therapeutics. The Taiwanese, for example, built a reliable mass production process for masks within about a month. ${ }^{13}$

These were preplanned and scientifically based response plans. The collective capabilities of preventing, detecting, and responding to health emergencies were in place or honed expeditiously in these nations at the onset of the pandemic. This is because these nations and their citizens recognised and ethically implemented obligations to address the mutual interdependences and shared vulnerabilities posed by the coronavirus.

Successful countries also required cooperation from their citizens, who accepted and fulfilled their moral obligations to do so. South Korea and Taiwan, for example, had learnt from SARS (severe acute respiratory syndrome) that wearing masks protects people from both contracting and spreading infection, ${ }^{14}$ and mandated wearing masks in public places, including transportation. ${ }^{15}$ They controlled the supply and distribution of face masks centrally so all received masks to keep themselves and others safe. ${ }^{16}$ This is social equality at work.

The citizens of the successful countries cooperate with authorities and with each other because they are committed to doing their part for the good of the whole. The 2003 SARS pandemic prepared Taiwan, South Korea, Japan, and New Zealand for covid-19; the 2008 recession prepared Germany, Finland, Austria, Iceland, and Norway. Justice commitments to protect every citizen from premature mortality and avoidable morbidity were in place before the covid-19 outbreak.

Similar justice principles safeguard the economy. In Germany, for example, societal capabilities were built to ensure temporary employment insurance through the Kurzarbeit, under which workers accept reduced hours and receive $60-67 \%$ of their wages (with this proportion increased during covid-19) from the Federal Employment Agency, returning to full time work once the crisis is over. ${ }^{17}$ Austria has a similar short time work scheme, ${ }^{7}$ and New Zealand has access to financial support. Along with cultural norms of problem solving and long term planning, successful nations created social institutions to deal with shared threats and vulnerabilities, in good times and bad.

These governments and their people quickly and willingly came together to stop covid-19. Even before the pandemic, these nations had baked these shared commitments into their national health insurance systems. Well planned, reliable measures ensured that together leaders and people were doing everything possible to provide top quality healthcare services to everyone. This equity orientation has led to some of the lowest covid-19 incidence and death rates worldwide. Principles of justice are essential if political institutions are to work effectively for population health.

\section{Rational, compassionate, and transparent} public communication

Throughout the covid-19 response, authorities in successful countries have addressed their populations with transparency, honesty, reason, and compassion. They've sought to earn the trust of their citizens and their support in following guidelines. This approach has fostered national unity, the principles and practice of impartiality and objectivity are key. Regular news conferences have provided reliable, accurate information, and scientifically grounded guidelines for action. ${ }^{1819}$ Government officials made clear that every person's life has equal value and the goal is to save everyone. These countries prize information transparency and accuracy, and news conferences acknowledged the disease's scope and severity rather than covering it up.

This honest approach reassured the public and engendered confidence. Rather than false reports and inaccurate assertions, government officials proved themselves to be trustworthy public servants, motivated by duty and guided by data. Officials prepared well for public 
communications, with accurate facts and figures. Their citizens felt safe rather than fearful, observing government actions that were smart, effective, and responsible. Approval ratings for these officials have been high, ${ }^{20}$ and citizens have willingly submitted to the government's authority. The Taiwanese, for example, believed government policies were orderly, efficient, and clearly justified.

\section{Ethical leadership and trust}

Successful nations enjoyed ethical leadership during the covid-19 pandemic. From the beginning, officials accepted responsibility and inspired others to embrace a shared purpose, to face a shared threat. They led from a sense of duty, not politics. Effective leaders do not politicise public health approaches for their own ends. They evince a deep respect for all. In Denmark, for example, citizens trust their government and leaders.

Of course, the countries that have successfully responded to covid-19 are not perfectly just; injustices exist and thwart flourishing. For example, South Korea and Japan remain patriarchal societies and also have unfair sexual orientation discrimination; racial and ethnic discrimination persists in Germany despite efforts to leave Nazism behind. Conversely, some equity oriented countries, such as Italy, fell short in fully protecting their citizens. Nevertheless, the successful countries are good examples of the justice framework and reflect characteristics identified as critical for a successful public health preparedness approach.

Democratic elections pressure politicians and parties to deliver on policies that are helpful rather than harmful, and to justify them, in order to meet people's needs. But deep core values underlie countries' policies and practices during and between times of crises. Just structures that foster security and express care and compassion are essential. A resilient society recognises shared risks and institutionalises shared safety, particularly for vulnerable groups. Justice was at work in nations that delivered resilient covid-19 responses. Justice, not politics, forms the foundation of what citizens owe each other and what leaders owe their citizens.

Competing interests: I have read and understood BMJ policy on declaration of interests and have no relevant interests to declare.

Provenance and peer review: Commissioned; externally peer reviewed.

This article is part of a collection launched at the World Health Summit, 25-27 October 2020, Berlin, Germany. Funding for the articles, including open access fees, was provided by a grant from Bloomberg Philanthropies to the Council on Foreign Relations, support from the Konrad-Adenauer-Stiftung to the Graduate Institute of International and Development Studies, and the Institute for Health Metrics and Evaluation.

Jennifer Prah Ruger, Amartya Sen professor of health equity, economics, and policy

University of Pennsylvania School of Social Policy and Practice and Perelman School of Medicine, Philadelphia, Pennsylvania, USA

Correspondence to: J P Ruger jenpr@upenn.edu

\section{@) $(1 \otimes)$ OPEN ACCESS}

This is an Open Access article distributed in accordance with the Creative Commons Attribution Non Commercial (CC BY-NC 4.0) license, which permits others to distribute, remix, adapt, build upon this work non-commercially, and license their derivative works on different terms, provided the original work is properly cited and the use is non-commercial. See: http://creativecommons.org/ licenses/by-nc/4.0/.

\section{Check for updates}

1 Ruger JP. Democracy and health. QJM 2005;98:299304. doi:10.1093/qjmed/hci042

2 Sen AK. Development as freedom. Random House, 1999.

3 Global Preparedness Monitoring Board. A world at risk: Annual report on global preparedness for health emergencies. World Health Organization, 2019:16.

4 Ruger JP. Positive public health ethics: toward flourishing and resilient communities and individuals. Am J Bioethics 2020;7:1-11.

5 Wittenberg-Cox A. What do countries with the best coronavirus responses have in common? Women leaders. Forbes 2020 Apr 13. https://www.forbes. com/sites/avivahwittenbergcox/2020/04/13/whatdo-countries-with-the-best-coronavirus-reponseshave-in-common-women-leaders/\#78c95ddc3dec.

6 Ayesh R. Two Asian coronavirus success stories face new wave of infections. Axios $2020 \mathrm{Apr}$ 18. https://www.axios.com/japan-singaporecoronavirus-infections-a617efde-3e04-4baf-9a65377f10454acf.html
7 Goedl M. What can we learn from Austria's response to COVID-19? 2020. https://keough.nd.edu/whatcan-we-learn-from-austrias-response-to-covid-19/

8 Ruger JP. Global health governance as shared health governance. J Epidemiol Community Health 2012;66:653-61. doi:10.1136/ jech.2009.101097

9 Japan to ask all travelers arriving from Europe, Egypt and Iran to self-quarantine. Japan Times 2020 Mar 19. https://www.japantimes.co.jp/ news/2020/03/19/national/abe-imposes-14day-quarantine-japan-arrivals-several-countrieseurope/\#.XsyFZWhKjic

10 Salcedo A, Yar S, Cherelus G. Coronavirus travel restrictions, across the globe. New York Times 2020 Jul 16. https://www.nytimes.com/article/coronavirustravel-restrictions.html

11 GardaWorld. Germany: authorities implement additional quarantine measures as of April 10 / update 19. GardaWorld 2020. https://www.garda. com/crisis24/news-alerts/329931/germanyauthorities-implement-additional-quarantinemeasures-as-of-april-10-update-19

12 Sui C. In Taiwan, the coronavirus pandemic is playing out very differently. What does life without a lockdown look like? NBC News 2020. https://www. nbcnews.com/news/world/taiwanese-authoritiesstay-vigilant-virus-crisis-eases-n1188781\#anchorstrongEpidemicpreventiontaxisandquarantinehotels strong

13 Ting-Fang C, Li L. Taiwan's “hidden champions” help coronavirus fightback. Nikkei Asian Review 2020 Apr 24. https://asia.nikkei.com/Business/Industry-infocus/Taiwan-s-hidden-champions-help-coronavirusfightback

14 Hille K, White E. Containing coronavirus: lessons from Asia. Financial Times 2020.Mar 16. https:// www.ft.com/content/e015e096-6532-11ea-a6cddf28cc3c6a68

15 Everington K. Masks mandatory on Taiwan trains, intercity buses starting today. Taiwan News 2020 Apr 1. https://www.taiwannews.com.tw/en/ news/3908366

16 Min-kyung J. South Korean government takes full control of face mask supply, bans exports. Korea Herald 2020 Mar 5, http://www.koreaherald.com/ view.php?ud=20200305000730

17 International Monetary Fund. Kurzarbeit: Germany's short-time work benefit. June 15. IMF Country Focus 2020. https://www.imf.org/en/News/ Articles/2020/06/11/na061120-kurzarbeitgermanys-short-time-work-benefit

18 Merkel A. Chancellor Merkel addresses the nation of Germany about coronavirus (English subtitles). YouTube 2020 Mar 18. https://youtu.be/ F9ei40nxKDc

19 Chen S. Taiwan sets example for world on how to fight coronavirus. ABC News 2020 Mar 13. https:// abcnews.go.com/Health/taiwan-sets-world-fightcoronavirus/story?id=69552462

20 Kinkartz S. Coronavirus: Angela Merkel's approval ratings up amid health crisis. DW News 2020 Apr 3. https://www.dw.com/en/coronavirusangela-merkels-approval-ratings-up-amid-healthcrisis/a-53001405

Cite this as: BMJ 2020;371:m4049 http://dx.doi.org/10.1136/bmj.m4049 